\title{
Geokjemi og helse
}

\author{
Bjørn Bølviken \\ Norges geologiske undersøkelse \\ E-post: bjorn.bolviken@ngu.no
}

\begin{abstract}
SAMMENDRAG
Artikkelen gir en oversikt over fagområdet geomedisin, også kalt medisinsk geologi. Fagfeltet kan defineres som vitenskapen om hvordan naturlige miljøfaktorer influerer på mennesker og dyrs helse. Mange eksempler viser at naturmiljøet kan være suboptimalt for helsen. I deler av Afrika og Asia er høyt innhold av fluor i drikkevann årsak til dental fluorose, i verste fall også skjelettskader. Særlig i Vest Bengalen og Bangladesh fører arsenholdig drikkevann til kreft og andre alvorlige sykdommer.

I Norge er det påvist mange relasjoner mellom naturforhold og husdyrsykdommer. Innen humanmedisin er det velkjent at underskudd på jod kan bidra til forekomst av struma, at tannråte har sammenheng med lavt fluorinnhold i drikkevann og at lungekreft kan være assosiert med høyt innhold av radon i boligluft. Radoninnholdet varierer også i takt med forekomst av multippel sklerose, men det er uklart om denne samvariasjonen er kausal. Det er ikke påvist noen signifikant sammenheng mellom innhold av kjemiske elementer i norsk drikkevann og rater for dødelighet eller sykelighet av utvalgte endemiske sykdommer.

Naturmiljøet kan påvirke menneskenes helse ved inntak av vann og mat, men faktorer som ioniserende og ultrafiolett stråling, støv i luften og kompliserte overføringsmekanismer via mellomverter er også mulig. Økologiske analyser kan avdekke tidligere ukjente samvariasjoner mellom sykdommer og naturmiljø, og derved gi grunnlag for nye etiologiske hypoteser.
\end{abstract}

Bølviken B. Geochemistry and health. Nor J Epidemiol 2004; 14 (2): 206-212.

\section{ENGLISH SUMMARY}

Geomedicine or Medical Geology can be defined as The science dealing with the influence of natural environmental factors on human and animal health. The geochemical environment is not always optimal for the health. In several regions in Asia and Africa, for example, high contents of fluorine in drinking water may cause mottled teeth and even skeletal deformations. Especially in West Bengal and Bangladesh millions of people are in danger of developing various types of cancer due to high levels of arsenic in the drinking water. In Norway, relations between the geochemistry of the environment and diseases in domestic animals are well known. Within human medicine causal associations have been found for caries versus fluorine deficiency and for goitre versus iodine deficiency. High levels of radon in Norwegian dwellings contribute to the development of lung cancer. Ecological analyses indicate that there is an association between radon and multiple sclerosis, but significant associations for levels of chemical elements in Norwegian drinking water versus rates of morbidity of cancer or mortality of some other selected endemic diseases were not detected.

For endemic diseases ecological analyses may disclose hitherto unknown correlations with properties of the environment, which may form the basis for suggesting new etiological hypotheses.

\section{INNLEDNING}

Fagområdet geomedisin, også kalt medisinsk geologi, kan defineres som vitenskapen om hvordan naturlige miljøfaktorer influerer på mennesker og dyrs helse (Låg 1978). Spesielt kjemiske, men også fysiske faktorer som klima og stråling er inkludert i definisjonen. Menneskeskapte forhold holdes utenfor. Internasjonalt er fagområdet omfattet med stor interesse, noe som for eksempel markeres ved at The International Union of Geological Sciences (IUGS) og The International Geological Correlation Programme har etablert prosjekter for medisinsk geologi (Adams 2001, Bailey 2001).

I Norge stammer trolig den første omtale av geomedisinske observasjoner fra geologen J.H.L. Vogt
(1888), som beskrev at forekomst av osteomalacia hos husdyr hadde sammenheng med underskudd på fosfor i beitegras (Låg 1989). Senere er det funnet flere tilsvarende korrelasjoner både for mangel på og overskudd av andre grunnstoffer hos husdyr (for eksempel Frøslie 1978 og Øvernes \& Frøslie 1992). En annen norsk geolog, professor T.F. Barth, observerte tidlig at det fluorholdige mineral turmalin er vanlig i noen områder med god tannhelse (professor J. Låg, personlig meddelelse 1998). J. Nicholaysen påviste lavt innhold av jod i matvarer og drikkevann fra områder med endemisk struma (Glattre 1982). I den siste halvpart av 1900-tallet har professor Låg vært den toneangivende forsker innefor geomedisin i Norge (Bergseth 1985, Låg 2000). I 1978 tok Låg initiativet til en Komité for 
Geomedisinsk Informasjon og Forskning under Det Norske Videnskaps-Akademi. Komitéen har til nå arrangert 15 nasjonale og internasjonale symposier innenfor fagområdet (www.dnva.no).

Hensikten med denne publikasjonen er å gi en oversikt over fagområdet geomedisin, illustrert ved hjelp av utvalgte eksempler på sammenhenger mellom naturmiljø og human helse. Noen viktige mekanismer for hvordan naturmiljøet kan påvirke vår helse blir kort omtalt. Assosiasjoner mellom naturmiljø og helse kan gi grunnlag for å fremme nye etiologiske hypoteser.

\section{NOEN EKSEMPLER PÅ SAMMENHENG MELLOM GEOKJEMI OG UTBREDELSE AV SYKDOM}

Mer enn tre millioner av de årlige dødsfall i verden skyldes vannbårne sykdommer (Tabell 1). Tabell 2 viser noen utvalgte eksempler på samvariasjon mellom geokjemiske data og sykdom. Tre av disse og en undersøkelse av drikkevann i Norge er nærmere beskrevet i det følgende.

\section{Arsenforgiftning}

Høyt innhold av det giftige grunnstoffet arsen i drikkevann er påvist mange steder $\mathrm{i}$ verden. Verst er forholdene i Vest Bengalen og Bangladesh. Tidligere ble overveiende overflatevann brukt til konsum i disse områdene. Dette vannet var i mange tilfeller infisert med sykdomsfremkallende mikroorganismer, noe som etter hvert har ført til at bakteriefattig grunnvann mer og mer er blitt tatt i bruk. Men dette har forårsaket et nytt problem: Når grunnvannstanden senkes ved utpumping, gjøres lag med arsenholdige mineraler i løsmassene tilgjengelig for oksygen. Dermed begynner den opprinnelig bestandige arsenkis å forvitre, og det dannes løselige arsenforbindelser, som havner i drikkevannet. Dette kan få et innhold opp til $2000 \square g$ As/1 (Kashem et al. 2000), noe som er meget høyt sammenlignet med WHOs anbefalte maksimalverdi på $10 \square \mathrm{g} / 1$ (WHO 1996). Det høye arseninnholdet har forårsaket en rekke helseproblemer som keratose og kreft i hud og andre organer. Chakraborti og medarbeidere (2004) angir at innenfor $500.000 \mathrm{~km}^{2}$ av Ganges, Meghna og Bramaputras elvesletter står 450 millioner mennesker i fare for å måtte drikke sterkt arsenholdig vann. I de mest utsatte områdene forventes at så mange som 1 av 10 dødsfall i de kommende år vil skyldes kreftformer initiert av høyt arseninnhold i drikkevannet. Dr. D. Chakraborti (personlig meddelelse) anklager her vestlig U-hjelp for å bidra til problemene ved å understøtte boring etter grunnvann. Etter hans mening ville man spare både penger og enorme menneskelige lidelser $i$ disse områdene ved å bruke renset overflatevann i stedet for grunnvann som drikkevannskilde.

\section{Fluorose}

Fluor er et essensielt grunnstoff, som likevel er skadelig, når det inntas $\mathrm{i}$ for store mengder (Fig. 1). I verdensmålestokk er overskudd av fluor i drikkevann et større problem enn underskudd, slik dette er påvist $\mathrm{i}$ Norge og noen andre land. Dental fluorose har lenge vært kjent i mange regioner, særlig i Asia og Afrika (Dissanayake 1996, Sampaio \& Fehr 2000). Denne lidelse kan være så skjemmende at den fører til sosiale problemer. Milde former av dental fluorose er observert også i Norge i forbindelse med høyt fluorinnhold i drikkevann (Bårdsen 1999).

Tabell 1. Antall personer (millioner per år) døde, syke eller i risikogruppe på grunn av vannbårne sykdommer i verden og noen land (Etter WHO 2004).

\begin{tabular}{llcrc}
\hline Sykdom & Område & Døde & Syke & $\begin{array}{c}\text { Risiko- } \\
\text { gruppe }^{1)}\end{array}$ \\
\hline Diaré & Verden & 1,8 & & \\
Malaria & Verden & 1,2 & & \\
Scistosomiasis (Bilharzia) & Verden & $>0,01$ & 160 & \\
Innvollsormer & Verden & 0,09 & 133 & \\
Trachoma & Verden & & 146 & 500 \\
Hepatitt A & Verden & & 1,5 & \\
Arsenforgiftning & Bangladesh & & 1,5 & 30 \\
Fluorose, dental & Kina & & 26 & \\
Fluorose, & & & & \\
skjelettdeformasjon & Kina & & 1,6 & \\
\hline
\end{tabular}

1) I risikogruppe for å få sykdommen som angitt av WHO.

Tabell 2. Geokjemi og endemiske sykdommer hos mennesker. Noen påviste geografiske samvariasjoner.

\begin{tabular}{llcl}
\hline Sykdom & Elementer & Kausal & Referanse \\
\hline Struma & $\mathrm{I}-$ & Ja & Glattre 1982, Dissanayake \& Chandraith 1996 \\
Tannråte & $\mathrm{F}-$ & $\mathrm{Ja}$ & Glattre 1982, Bårdsen 1999 \\
Fluorose & $\mathrm{F}+$ & $\mathrm{Ja}$ & Årflot 1981, Sampaio \& Fehr 2000 \\
Lungekreft & $\mathrm{Rn}+$ & $\mathrm{Ja}$ & BEIR V 1990 \\
Keshan sykdom & $\mathrm{Se}-$ & $\mathrm{Ja}$ & Jinan 1985 \\
Kashin-Beck sykdom & $\mathrm{Se}-\mathrm{I}-$ & $\mathrm{Ja}$ & Jinan 1985 \\
Arsenforgiftning & $\mathrm{As}+$ & $\mathrm{Ja}$ & Kashem et al. 2000, Chakraborti et al. 2004 \\
Leukemi & $\mathrm{Rn}+$ & $?$ & Henshaw \& Allen 2002 \\
Nesesvelg-kreft & $\mathrm{Th}+\mathrm{U}+\mathrm{Mg}-$ & $?$ & Bølviken et al. 1997b, Bølviken 2000 \\
Multippel sklerose & $\mathrm{Rn}+\mathrm{Mg}-$ & $?$ & Bølviken et al. 2003 \\
\hline
\end{tabular}

+: For mye, overskudd $\quad$-: For lite, underskudd 


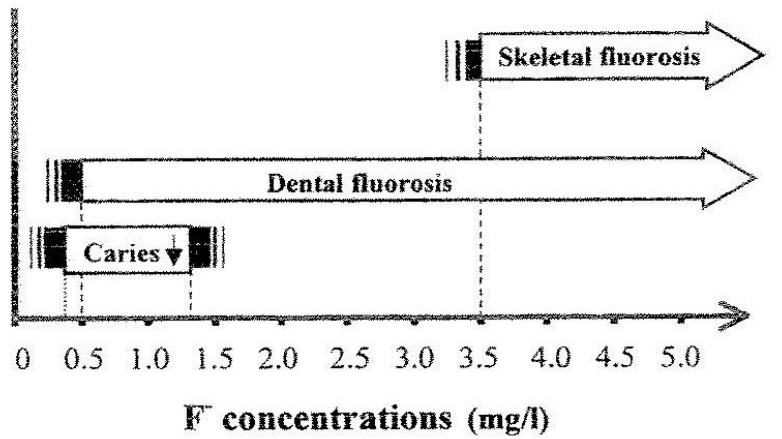

Figur 1. Effekter av ulike konsentrasjoner av fluor i drikkevann. Etter Sampio \& von der Fehr (2000).

I varmt klima med stort vannkonsum regnes drikkevann å være kilde for ca. $75 \%$ av fluorinntaket (Formon \& Ekstrand 1996). Med et fluorinnhold på mer enn ca. $4 \mathrm{mg} / \mathrm{l} \mathrm{kan} \mathrm{drikkevannet} \mathrm{da} \mathrm{forårsake}$ alvorlige skjelettskader (Årflot 1981, Jinan 1985, Sampaio \& von der Fehr 2000).

I likhet med den uttrykte skepsis til bruk av arsenholdig grunnvann, er det også ytret kritikk mot vestlig U-hjelp for å understøtte konsum av fluorholdig grunnvann uten å introdusere rensemetoder (Dr. C.B. Dissanayake, personlig meddelelse).

\section{Assosiasjoner mellom multippel sklerose (MS) og miljoparametre $i$ Norge}

Årsaken til MS er ikke kjent, men det er enighet blant forskerne om at tre faktorer, nemlig arv, virus og miljø spiller en rolle (Mathews et al. 1991). Sammenlignet med mange andre land har Norge høy prevalens av MS (Finhaber \& Lauer 1994). I Sør-Norge viser forekomsten av MS en systematisk fordeling med relativt lave rater langs kysten og høye rater i innlandet (Fig. 2). Dette kan tyde på at en eller flere miljøfaktorer er av betydning (Franklin \& Nelson 2003).

Den geografiske fordeling av MS ble sammenlignet med utvalgte miljøparametre ved hjelp av løpende korrelasjon (Bølviken et al. 1997a, 2003). Denne metoden beregner korrelasjonen mellom parvise måledata (i dette tilfelle rater av MS og en miljøparameter karakteristisk for hvert av 73 delområder i Norge). Delområdene består av nabokommuner aggregert til enheter med minst 10.000 innbyggere. Bare rurale kommuner inngår i aggregatene, som er illustrert som målepunkter på kartet i Fig. 3. Et sirkulært vindu defineres for de $n-1$ nærmeste målepunkter rundt et tilfeldig målepunkt på kartet. Deretter beregnes korrelasjonskoeffisienten (Spearman rank) mellom sykdomsrate og miljøparameter for alle målepunkter $(n)$ innenfor vinduet. Den oppnådde verdi plottes på kartet som et symbol i vinduets midtpunkt (sirkelens sentrum). Deretter defineres et nytt sirkulært vindu med $n-1$ nabopunkter rundt et annet målepunkt på kartet. Korrelasjonskoeffisienten for dette vinduet beregnes og plottes på samme måte som for første vindusposisjon. Denne

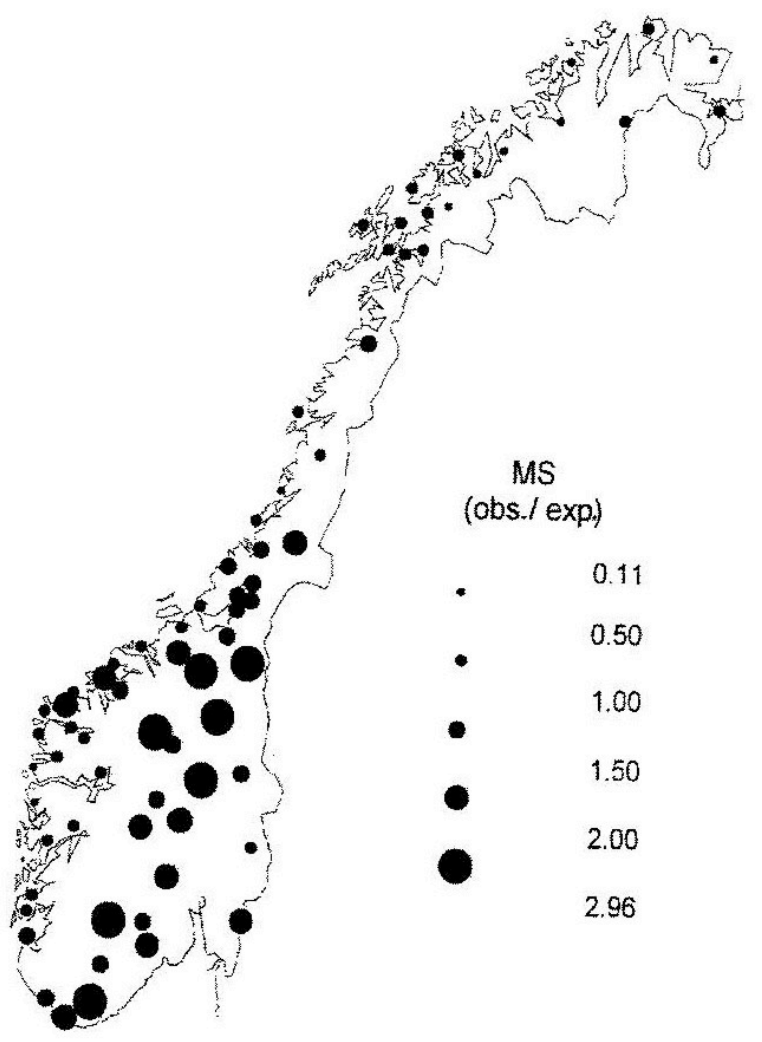

Figur 2. Forekomst av multippel sklerose i Norge. Størrelsen på punktene symboliserer rater for summen av dødelighet og uførhet i rurale kommuneaggregater, beregnet etter verdier publisert av Westlund (1982), Bølviken et al. (2003).

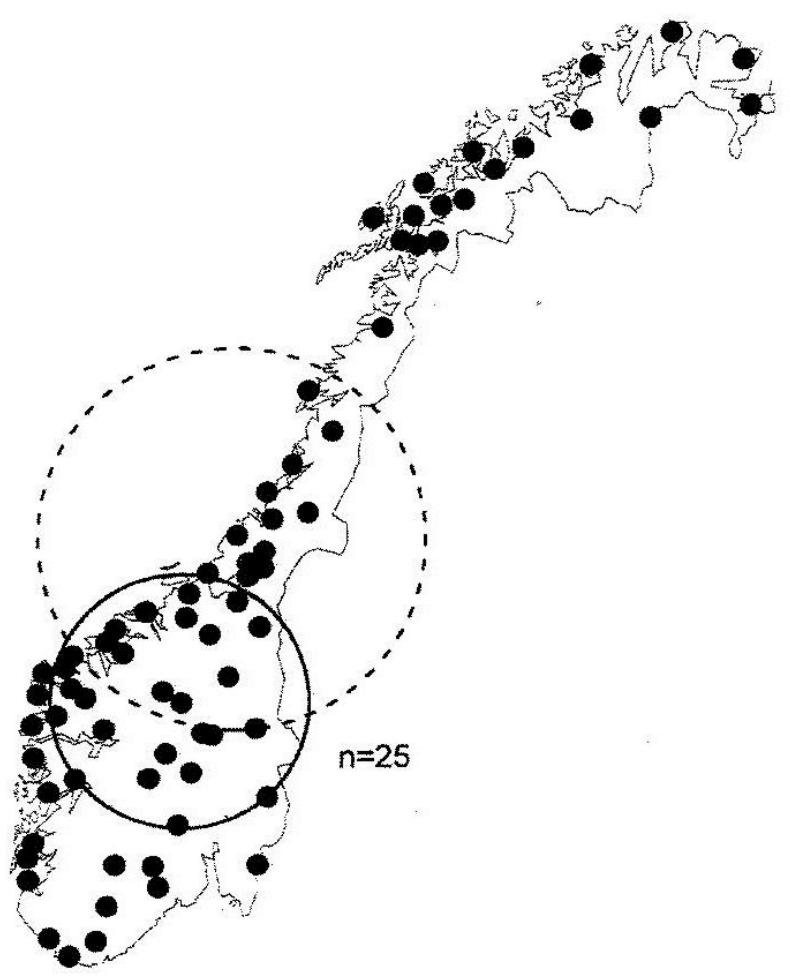

Figur 3. Illustrasjon av metode for beregning av løpende korrelasjon for rater av en sykdom versus måledata for en forklaringsparameter. Korrelasjonen beregnes for hver mulig sirkelposisjon på kartet, her 73 . 
prosedyre gjentas for alle mulige posisjoner av vinduet. Det fremkommer et kart over korrelasjonskoeffisienter for overlappende delarealer. Ved ujevn observasjonstetthet vil størrelsen på vinduet variere med posisjon på kartet, men korrelasjonskoeffisientenes antall frihetsgrader $(n-2)$ er konstant over hele kartet.

Antall målepunkter innenfor det løpende vindu $(n)$ velges slik at det oppnås best mulig kompromiss mellom stor oppløselighet (lav $n$ ) og akseptabel presisjon (høy $n$ ) i korrelasjonsanalysene. Signifikansen av de oppnådde korrelasjonskoeffisienter testes ved å sammenligne med resultater av tilsvarende analyser for 1000 ulike sett med permuterte data.

Det ble funnet at for aggregater av rurale nabokommuner i Sør-Norge øker forekomsten av MS med innholdet av radon i boligluft, mens den minker med nedfall av sjøsalter. Begge disse korrelasjoner er statistisk signifikante. Samvariasjonen med Rn er tydeligst på Vestlandet (Fig. 4). Fordelingsmønsteret for korrelasjonen MS versus radon lar seg tolke som resultat av et samspill mellom radonavgivelse fra undergrunnen og nedfall av sjøsalter uttrykt ved innholdet av magnesium i nedbør (Bølviken et al. 2003).

Funnene bidrar til å underbygge en foreslått hypotese om radon som en mulig årsaksfaktor for MS (Lauer 1995, Prater \& Eidbo 1998, Gilmore \& Grennan 2003). Denne naturlig forekommende radioaktive edelgass er påvist $\mathrm{i}$ forholdsvis store konsentrasjoner $\mathrm{i}$ inneluften i norske boliger (Strand et al. 1991, Henriksen et al. 1995). De høye nivåer skyldes de geologiske forhold i vårt land og forsterkes av norske byggeskikker, og at vi har en lang fyringssesong med store forskjeller i temperaturen inne og ute.

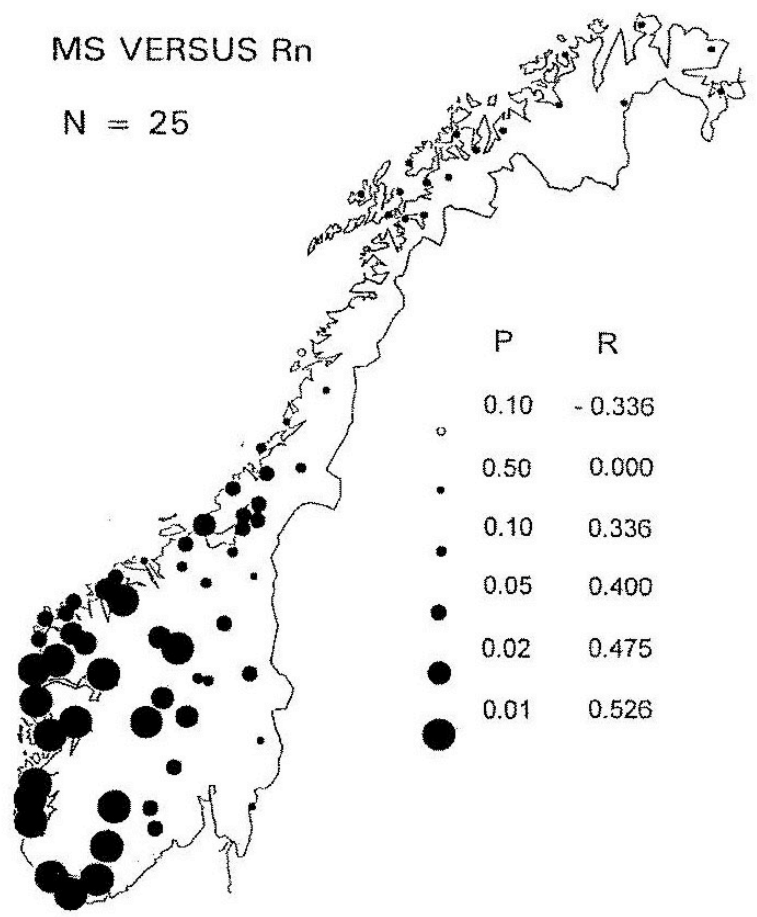

Figur 4. Løpende korrelasjon for rater av multippel sklerose (Westlund 1982) versus innholdet av radon i boligluft (Bølviken et al. 2003).
I Norge er det senere funnet at MS er mer prevalent blant røkere enn blant ikke røkere (Riise et al. 2003). Synergisme mellom tobakksrøking og radon er tidligere påvist $\mathrm{i}$ forbindelse med lungekreft (BEIR V 1990). Det er derfor av interesse å undersøke om en tilsvarende synergisme eksisterer $\mathrm{i}$ forbindelse med MS. Dette tilsier at selv om hypotesen om radon som en årsaksfaktor ved MS er usikker, bør de oppnådde resultater følges opp med videre studier.

\section{Drikkevann i Norge}

Flaten (1991) samlet inn representative vannprøver fra 384 norske vannverk, som forsyner mer enn $70 \%$ av befolkningen i sitt distrikt. Prøvene ble analysert på 27 grunnstoffer og i tillegg på parametre som farvetall og elektrisk ledningsevne. I en økologisk studie ble analyseresultatene korrelert med insidens 1975-84 av 15 grupper av kreft og dødelighet av 16 andre sykdommer (Flaten \& Bølviken 1991). Det ble registrert systematiske geografiske fordelinger i sammensetningen av drikkevannet. Noen av disse, for eksempel mønstrene for $\mathrm{Al}$ og $\mathrm{Mg}$, er påvirket av lang- og korttransportert forurensning, men de fleste kan tolkes som effekter av naturforholdene. For eksempel er fordelingene av elementer som $\mathrm{Cl}$ og $\mathrm{Br}$ tydelig påvirket av nedfall av naturlige sjøsalter. Det ble ikke funnet sikre sammenhenger mellom sykdomsdata og geokjemiske data. Dette behøver ikke nødvendigvis å bety at slike korrelasjoner ikke finnes i Norge. Det kan tenkes at effektene er for små til å bli avdekket $\mathrm{i}$ et materiale av denne størrelse med de metoder som ble brukt.

\section{HVORDAN KAN NATURMILJØET PÅVIRKE MENNESKENES HELSE?}

\section{Oralt inntak}

Drikkevannet avspeiler de lokale og regionale geokjemiske og biologiske forhold. Dette gjelder både for grunnvann og overflatevann, noe som innebærer at det geokjemiske miljø kan være en grunnleggende faktor bak helseforholdene i befolkningsgrupper. I sin tur avspeiles de geokjemiske forhold også i den lokale vegetasjon som derved kan påvirke menneskenes helse også via føden. Mulighetene for dette er størst der menneskene lever under enkle forhold i nær tilknytting til naturen, slik som i mange U-land. Men selv i vår del av verden med velutviklet internasjonal varehandel vil både visse vegetabilske og animalske næringsmidler i noen grad bli konsumert innenfor eller nær det landområde der produktene er dyrket. En direkte refleksjon av de geokjemiske forhold ved tilfeldig inntak av små mengder jord og støv via føde og skitne hender er også en mulighet (Thornton 1984).

\section{Andre mekanismer}

Oralt inntak er ikke den eneste måten geokjemien kan påvirke helsen i befolkningsgrupper på. En rekke faktorer peker mot mange andre muligheter: 
- Luften vi puster inn inneholder partikler og vannoppløste salter. En del av dette materialet vil være antropogent, men visse fraksjoner kan være naturlige og avspeile regionale og lokale geokjemiske forhold, slik disse er reflektert i jordsmonn, vegetasjon og overflatevann (Pacyna 1992). Avhengig av avstand fra kysten vil luft og nedbør ha et stort eller lite innslag av naturlige sjøsalter (Bølviken 1992). Bestanddeler i luft kan opptas direkte gjennom hudog lungeepitel eller ved at innåndet støv og annet materiale blir avsatt $i$ åndedrettsorganene, for senere å bevege seg oppover luftrøret og etter hvert havne i fordøyelseskanalen (Wagner 1980).

- Naturlig ioniserende stråling kan påvirke helsen i varierende grad etter hvor menneskene bor, arbeider eller oppholder seg i sin fritid, fordi innholdet av radioaktive elementer $\mathrm{i}$ undergrunn, vann og luft varierer både lokalt og regionalt (Bølviken 2002). I Norge er radongass med datterprodukter av særlig interesse, fordi inneluften hos oss i mange tilfeller er anriket på radon. Årsakssammenhenger mellom forekomst av lungekreft og radoninnholdet i luft er fastslått (BEIR V 1990). Tilsvarende forhold er foreslått også for andre sykdommer, som samvarierer med forekomsten av radon eller andre radioaktive elementer (Tabell 2). Solstråling kan føre til hudkreft og påvirker ellers årsrytmer i helsetilstand (Moan 2004). Det er også vist at ultrafiolett stråling kan føre til reaktivering av latent virus med påfølgende oppblussing av herpes simplex (Oakley et al. 1997). Muligheten for at naturmiljøet kan bidra til reaktivering av andre typer virus bør derfor ikke neglisjeres.

- Naturmiljøets påvirkning av menneskenes helse kan innebære mekanismer over flere ledd. Et eksempel fra dyrelivet illustrerer dette. En farlig parasitt på rein, hjernemarken Elaphost ronghyis rangifera, har en fuktighet- og kalsiumkrevende snegle som mellomvert (Nordkvist 1984). Det må derfor eksistere en sammenheng mellom forekomst av hjernemark på rein og parametre som nedbør, temperatur og innholdet av kalsium i jord. Tilsvarende typer kom- pliserte assosiasjoner kan ikke utelukkes også hos mennesker. For eksempel er det velkjent at pollen kan fremkalle allergier hos noen mennesker. Pollenproduksjonen varierer med vær og klima og avhenger ellers av den lokale og regionale plantesosiologi, som i sin tur reguleres av en rekke miljøfaktorer, deriblant jordsmonnets naturlige kjemiske sammensetning.

- I klinisk medisin er det utallige eksempler på at naturlige kjemiske forbindelser kan hemme sykdomsagenser. Synergisme mellom skadelige agenser er også kjent. Et eksempel på dette er at samtidig eksponering for radon, asbest og tobakksrøyk gir større sjanse for lungekreft enn det summen av disse agenser gjør ved enkeltvis påvirkning (BEIR V 1990). Av spesiell interesse i denne sammenheng er fenomenet hormese. Dette begrepet innebærer at dose-responskurven for en skadelig agens ikke er lineær. Ved lave doser kan responsen nå et minimum for så å øke ved ytterlig avtagende dose (Pettersen 2002, Calabrese \& Baldwin 2003).

\section{KONKLUSJON}

Dersom kjennskapet til etiologien av en endemisk sykdom er ufullstendig, bør data om dens geografiske utbredelse være et godt utgangspunkt i den videre epidemiologiske forskning. Sammenstilling av slike data med tilsvarende data for mulige forklaringsvariable er en aktuell arbeidsmåte innen geomedisin. Erfaringer fra mange land tyder på at dette fagområdet kan bidra med verdifulle forskningsresultater i slike sammenhenger. De resultater som hittil er oppnådd, indikerer at det vil være gode muligheter for å finne interessante geomedisinske assosiasjoner både $\mathrm{i}$ eksisterende og $\mathrm{i}$ fremtidige empiriske data. Samvariasjoner påvist ved økologiske analyser av denne type, gir ikke uten videre grunnlag for å fastslå årsaker. Påviste korrelasjoner kan likevel brukes til å fremme etiologiske hypoteser, som vil kunne vurderes nærmere ved andre undersøkelser.

\section{REFERANSER}

Adams SS, 2001. Geosciences \& Human Health (Temanummer). Geotimes 46 (11): 20-36.

Bayley D (Red.), 2001. Geology and health. Eartwise Issue 17. British Geological Survey, Nottingham. 34 pp.

BEIR V, 1990. Health effects of exposure to low levels of ionizing radiation. Committee on Biological Effects of Ionizing Radiations, Washington D.C: National Research Council, National Academy Press, 421 pp.

Bergseth H, 1985. Jul Lågs skriftlige arbeider 1942-1984. Jord og Myr 9 (5): 275-285.

Bølviken B, 1992. Influence of chemical climate on regional geochemical distribution patterns. I: Låg J (Red.), Chemical climatology and geomedical problems. Det Norske Videnskaps-Akademi, 73-82.

Bølviken B, 2000. Relationships between nasopharyngeal carcinoma and radioactive elements in soils in China. Med Hypotheses 55: 513-516.

Bølviken B (Red.), 2002. Natural ionizing radiation and health. Det Norske Videnskaps-Akademi, 177 pp.

Bølviken B, Nilsen R, Ukkelberg Å, 1997a. A new method for spatially moving correlation analysis in geomedicine. Environ Geochem Health 18: 143-153. 
Bølviken B, Flaten TP, Zheng C, 1997b. Relations between nasopharyngeal carcinoma and magnesium and other alkaline earth elements in soils in China. Med Hypotheses 48: 21-25.

Bølviken B, Celius EG, Nilsen R, Strand T, 2003. Radon: a possible risk factor in multiple sclerosis. Neuroepidemiology 22: 87-94.

Bårdsen A, 1999. A study of fluoride in groundwater and dental fluorosis. Doktoravhandling, Odontologisk fakultet, Universitetet i Bergen.

Calabrese EJ, Baldwin LA, 2003. Toxicology rethinks its central belief. Nature 421: 691-992.

Chakraborti D, Sengupta MK, Rahman MM, et al, 2004. Groundwater arsenic contamination and its health effects in the Ganga-Meghna-Bramaputra plain. J Environ Monit 6: $74 \mathrm{~N}-83 \mathrm{~N}$.

Dissanyake CB, 1996. Water quality and dental health in the dry zone of Sri Lanka. I: Appleton JD, Fuge R, McCall JH (Red.), Environmental geochemistry and health. The Geological Society, London, 131-140.

Dissanyake CB, Chandraith RLR, 1996. Iodine in the environment and endemic goitre in Sri Lanka. I: Appleton JD, Fuge R, McCall JH (Red.), Environmental geochemistry and health. The Geological Society, London, 213-221.

Firnhaber W, Lauer K (Red.), 1994. Multiple sclerosis in Europe. An epidemiological update. LeuchturmVerlag/LTV Press, 350 pp.

Flaten TP, 1991. A nation-wide survey of the chemical composition of drinking water in Norway. Sci Total Environ 102: 35-73.

Flaten TP, Bølviken B, 1991. Geographical associations between drinking water chemistry and the mortality and morbidity of cancer and some other diseases in Norway. Sci Total Environ 102: 75-100.

Formon SJ, Ekstrand J, 1996. Fluoride intake. I: Fejerskov O, Ekstrand J, Burt BA (Red), Fluoride in dentistry, Munksgaard, København, 40-52.

Franklin GM, Nelson L, 2004. Environmental risk factors in multiple sclerosis. Neurology 61: 1032-1034.

Frøslie A, 1978. Copper in sheep in Norway. I: Låg J (Red.), Geomedical aspects in present and future research. Det Norske Videnskaps-Akademi, 183-195.

Gilmore M, Grennan E, 2003. A pilot study of the relationship between multiple sclerosis and the physical environment in Northwest Ireland. Environ Geochem Health 25: 157-163.

Glattre E, 1992. Geomedisin. I: Natvig H, Bjerkedal T, Høstmark AT, Velar OD (Red.), Forebyggende medisin. Gyldendal, 10-20.

Henriksen T, Ingebretsen F, Storruste A, Strand T, Svendby T, Wethe P, 1995. Stråling og helse. Oslo: Fysisk institutt, Universitetet i Oslo, 209 pp.

Henshaw DL, Allen JE, 2002. Is indoor radon linked to leukaemia in children and adults? I: Bølviken B (Red.), Natural Radiation and Health. Det norske Videnskaps-Akademi, 127-147.

Jinan T (Red.), 1985. The atlas of endemic diseases and their environments in the People's Republic of China. Science Press, Beijing.

Kashem AM, Singh BR, Huq SMI, 2000. Arsenic in drinking waters - a calamity to human health in Bangladesh. I: Låg J (Red.), Geomedical problems in developing countries. Det Norske Videnskaps-Akademi, 125-135.

Lauer K, 1995. Environmental associations with the risk of multiple sclerosis: the contribution of ecological studies. Acta Neurol Scand Suppl 161: 77-88.

Låg J, 1978. Survey of geomedical problems, including some examples from investigations carried out in Norway. I: Låg J (Red.), Geomedical aspects in present and future research. Det Norske Videnskaps-Akademi, 11-19.

Låg J, 1989. Osteomalacia causally related to low phosphorous concentrations: an important geomedical discovery in Norway 100 years ago. Soil Sci 148: 284-285.

Låg J, 2000. Geomedical problems in developing countries. Det Norske Videnskaps-Akademi, $241 \mathrm{pp}$.

Matthews WB, Compton A, Allen IV, Martyn C (Eds.), 1991. McAlpine's Multiple Sclerosis. Edinburgh, 2-40.

Moan J, 2004. Lys, døgnrytmer og vinterdepresjoner. P2-akademiet, Bind XXXI, Transit, 71-80.

Nordkvist M, 1984. Some reindeer diseases from a geomedical point of view. I: Låg J (Red.), Geomedical research in relation to geochemical registrations. Det Norske Videnskaps-Akademi og Universitetsforlaget, 147-151.

Oakley C, Epstein JB, Sherlock CH, 1997. Reactivation of oral herpes simplex virus. Oral Surg Oral Med Oral Pathol 84: 272-278.

Pacyna JM, 1992. Contribution to the atmosphere from natural sources. I: Låg J (Red.), Chemical climatology and geomedical problems. Det Norske Videnskaps-Akademi, 91-105.

Pettersen EO, 2002. Low-dose hypersensitivity and adaptive responses to radiation. I: Bølviken B (Red.), Natural ionizing radiation and health. Det Norske Videnskaps-Akademi, 92-102.

Prater MP, Eidbo WB, 1998. Multiple sclerosis and ionizing radiation. Paper submitted at the Health of the Hanford site Conference, Richland, Washington, 8 pp.

Riise T, Nortvedt MW, Ascherio A, 2003. Smoking as a risk factor for multiple sclerosis. Neurology 61: 11221124. 
Sampaio FC, von der Fehr FR, 2000. Fluoride as geomedical problem in developing countries. I: Låg J (Red.), Geomedical problems in developing countries. Det norske Videnskaps-Akademi, 98-111.

Smedley P, 2001. Arsenic in groundwater. I: Bayley D (Red.), Geology and Health. British Geological Survey. Eartwise, Issue 17, 8-9.

Strand T, Green BMR, Lomas PR, Magnus K, Stranden E, 1991. Radon i norske boliger. Statens institutt for strålehygiene, $3: 24 \mathrm{pp}$.

Thornton I, 1984. Environmental geochemistry and health in the United Kingdom. I: Låg J (Red.), Geomedical research in relation to geochemical registrations. Universitetsforlaget, 125-136.

Vogt JHL, 1888. Norske ertsforekomster. V Titanjernforekomsterne i noritfeltet ved Ekersund-Soggendal. Archiv for Mathematik og Naturvidenskap 12: 1-101.

Wagner JC, 1980. The pneumoconiosis due to mineral dusts. J Geol Soc 137: 537-545.

Westlund K, 1982. Recent statistical data on multiple sclerosis and some other diseases in Norway. Nord Council Arctic Med Res 32: 19-29.

WHO, 1996. WHO guidelines for drinking-water quality. Vol 2, 2nd edn. World Health Organization.

WHO, 2004. Water Sanitation and Hygiene links to health. World Health Organization.

www.dnva.no. Det Norske Videnskaps-Akademi, hjemmeside.

Øvernes G, Frøslie A, 1992. Geographical distribution of iodine and selenium deficiency in animals. I: Låg J (Red.), Chemical climatology and geomedical problems. Det Norske Videnskaps-Akademi, 33-39.

Årflot O, 1981. Fluor og fluorider hos mennesker, dyr og planter. Landbruksforlaget, 198 pp. 